\title{
FACILITIES OF BREAD ENRICHMENT WITH CALCIUM BY USING EGGSHELL POWDER
}

\author{
Vijole Bradauskiene, Kristina Montrimaite, Elena Moscenkova \\ Department of Food Technology, Faculty of Technology, Klaipeda State University of Applied Sciences, Bijunu str. 10, \\ Klaipeda, Lithuania, e-mail:v.bradauskiene@kvk.lv
}

\begin{abstract}
Today's food ration does not often contain enough vitamins, fibre, macro- and micronutrients, especially calcium. Research aim: to study possibilities for the use of the eggshell powder in the production of bread enriched with calcium. For the study, the free-range hen eggshells, main components of which are inorganic salts, were used. The eggshells have been washed, dried and ground. To avoid changes in the texture of bread, the solubility of the eggshell powder was tested by incorporating different quantity of eggshell powder $(2.5 \mathrm{~g}$,) into rye sourdough with Lactobacilli for 12 hours. After discovering good solubility of the eggshell powder in the fermented leaven samples, sourdough of rye bread was prepared (control, 2.5, 5.0, 7.5, 10.0, $12.5 \mathrm{~g}$ addition of eggshell powder) and using them six samples of wheat bread were baked. To estimate an influence of eggshell powder on a product quality and acceptability of bread by consumers, sensory evaluation for bread samples was carried out. Besides porosity, moisture content, acidity, the actual acidity, specific volume of bread were defined, and also nutritional value and amount of calcium were calculated. The study showed that when making the bread enriched with calcium, it is recommended to add an eggshell powder to rye sourdough with lactic acid bacteria. The sensory evaluation shows that the bread with eggshell powder had a better appearance of the crust, colour of the crumb, flavour and overall acceptability compared to control bread, however the taste and flavour remained similar or got worse. By increasing the amount of eggshells, bread porosity and specific volume of bread increased, while acidity and active acidity decreased. Bread containing $5.0 \mathrm{~g}$ of eggshell powder was marked as a bread of the best quality.
\end{abstract}

Keywords: Eggshell powder, calcium carbonate, bread, lactic sourdough.

\section{Introduction}

Calcium $(\mathrm{Ca})$ is one of the important macronutrients necessary for normal functioning of the human body. Calcium is not only the major component of bones and teeth, it also participates in the regulation of hormone secretion and activation, muscle contraction, neuronal conduction via ion channels, regulation of inflammatory processes, maintaining the permeability of cell membranes, and many others (Dri et al., 2011). Deficiency of calcium in the diet causes bone loss or osteoporosis. Studies have found that only 10 percent of adults consume adequate calcium dose with food. Older people get with food only $606.02 \pm 217.35 \mathrm{mg}$ of calcium per day (Tamulaitiene et al., 2006). This is below the acceptable daily consumption of calcium. It is therefore very important to ensure an adequate amount of calcium in the diet. This can be achieved by the use of calcium supplements, but calcium is better absorbed when consumed in small amounts throughout the day, so nutritional fortification with calcium is a good solution. (Romanchik-Cerpovicz et al., 2007). Results of study (Juma et al., 1999) indicate that enriched bread can serve as a good source of bioavailable calcium. Calcium absorption was significantly higher in the bread in comparison to the milk and control groups. In addition, the use of eggshells can contribute to the reduction of waste.

It was thought that the eggshell is not a usable product, but opinion has changed after extensive research (Daengprok et al., 2003). It was suggested that eggshell calcium promoted strengthening bones and improving their growth.

Several Ca sources are available for food fortification. $\mathrm{CaCO}_{3}$ is the most widely used $\mathrm{Ca}$ salt because $40 \%$ of the compound is well absorbable $\mathrm{Ca}$. This $\mathrm{Ca}$ salt can be formulated from $\mathrm{Ca}(\mathrm{OH})_{2}$ or chalk but can also be derived from fossilized or fresh shells (e.g., chicken eggshell and oyster shell). The egg consists of $9.5 \%$ eggshell, 63\% egg white (albumen) and $27.5 \%$ yolk. Eggshell components are inorganic salts $(91.87 \%)$, the main ones of which are calcium carbonate $(98.4 \%)$, magnesium carbonate $(0.8 \%)$, tricalcium phosphate $(0.8 \%)$ (Dri et al., 2011). Chemical composition of white and brown eggshells is slightly different. A little more calcium is in a white eggshell powder (34.12 $\pm 0.10 \%$ in white; $33.13 \pm 0.10 \%$ in brown), but in brown - more magnesium, phosphorus and potassium (EP 2780114 A1). Natural Ca sources are of interest because they contain not only $\mathrm{Ca}$ but also other elements (e.g., Sr and F), which may have a positive effect on bone metabolism (Olgun et al., 2015). Concentrations of other elements (Na, K, P) in eggshells are very low compared to the daily recommended allowance (Neunzehn et al., 2015). Studies have proven natural calcium supplement safety - eggshell powder has a smaller amount of $\mathrm{V}$, $\mathrm{Cr}, \mathrm{Pb}, \mathrm{Al}$, and $\mathrm{Cd}$ compared to oyster shells or purified $\mathrm{CaCO}_{3}$ (Schaafsma et al., 2000). Least quantity of hazardous heavy metals - mercury and cadmium is in the organic eggs and in the eggs from free-range hens (Schaafsma et al., 2000).

There is a number of registered patents how to separate the egg inner membrane from the eggshell. One of the best ways - eggshells should be treated by the high air velocity at ambient temperature, thus preserving the original shell and membrane lipids and protein structure (EP 2780114 A1).

There are few papers describing the use of chicken eggshells as $\mathrm{Ca}$ supplement in human beings. Schaafsma et al. (2000) showed an increase in lumbar spine, total proximal femur and trochanter bone mineral density in osteoporotic postmenopausal women 
who received eggshell powder with vitamin $D_{3}$. Chicken eggshell powder (ESP) has been proposed as an attractive source of calcium for human health to increase bone mineral density in an elderly population with osteoporosis (Rovenský et al., 2002). Chicken eggshell contains about $1.0 \%$ matrix proteins in addition to a major form of calcium carbonate $(95 \%)$. Soluble eggshell matrix proteins that remarkably enhance calcium transport in to cells and the potential significance of eggshell calcium as a nutraceutical are discussed (Daengprok. et al., 2003).

Hirasawa et al. (2001) showed that eggshell calcium is one of the most effective sources of $\mathrm{Ca}$ - eggshell Ca could have greater effects to $\mathrm{CaCO}_{3}$ on bone metabolism. In contrast with $\mathrm{CaCO}_{3}$, vitamin $\mathrm{D}_{3}$ supplementation did not significantly increase $\mathrm{Ca}$ content. Studies showed that calcium absorption from eggshell powder is slightly higher $(45.59 \%)$ than from $\mathrm{CaCO}_{3}(39.88 \%)$ and other calcium supplements (Brun et al., 2013).

It is often assumed that the calcium carbonate is poorly absorbed by the body because of its insolubility. Maybe calcium citrate or calcium lactate soluble in water (in such a form it is present in milk) is better absorbed (Szeleszczuk et al., 2015). Calcium solubility in vitro study (Bradauskienè et al., 2016) demonstrated that calcium carbonate from eggshell is readily soluble in gastric juice comparing to solubility of other commercial calcium supplements such as Calcigran ${ }^{\circledR}$, Calcivit ${ }^{\circledR}$ Coral Calcium ${ }^{\circledR}$. In vitro study showed that in the $0.1 \mathrm{M} \mathrm{HCl}, \mathrm{pH}=1.00$ solution the eggshell powder is dissolved at $37^{\circ} \mathrm{C}$ temperature within $90 \mathrm{~min}$ to $75.0 \pm 4.5 \%$.

The eggshell of one egg contains $2.07 \pm 0.18$ grams of calcium (Dri et al., 2000). This means that half of an eggshell can provide the amount of $\mathrm{Ca}$ needed per day in adult human beings. Argentine scientists Brun et al. (2013) provide methods that are easy to use at home. One of them - to dissolve the eggshell powder in lemon or orange juice or vinegar solution. Eggshell powder was added to bread, breaded fried meat, pizza and spaghetti. The sensory evaluation shows no change in the taste, but changes in the texture were identified that may not be acceptable to consumers, so the authors advise to look for ways to avoid them (Brun et al., 2013).

The calcium additives are particularly useful for fortifying leavened baked goods with calcium. Methods for preparing the calcium additives and using the calcium additives to fortify baked goods are also patented (US8221808). Generally, the calcium additives comprise intimate admixtures of calcium carbonate and an acid such as citric acid.

In previous research carried out by Food Technology Department of Klaipeda State University of Applied Sciences, seeking to enrich traditional Lithuanian light bread with calcium, eggshell powder (ESP) (2.5 g) was added to a leavened bread dough. The dough was allowed to rise for 5 hours, but in all cases undesirable texture changes in the baked bread were identified undissolved eggshell powder was perceptible during bread chewing. The next experiment discovered that the ESP perfectly dissolved in rye leaven and graininess in baked bread was not perceptible, so it was decided to bake bread using rye sourdough with lactic acid and incubating the eggshell powder in it. The aim of this study: to study possibilities for the use of the eggshell powder in the production of bread enriched with calcium.

\section{Materials and Methods}

For the study brown eggshells of free range chicken, 7-8 days old, were used, average mass of one egg was $58 \pm 2.38 \mathrm{~g}$, eggshell mass was $5.43 \pm 0.79 \mathrm{~g}$. Eggshells were prepared properly: thoroughly washed, the inner membrane was removed, dried in oven for 15 minutes at $+63 \pm 0.3{ }^{\circ} \mathrm{C}$ degrees, grinded up in a coffee grinder and crushed in a ceramic mortar and pestle.

Preparation of bread with ESP

Semi-wheat bread samples were prepared at Laboratory for Food Technologies at Klaipeda State University of Applied Sciences in accordance with the leavened bread production technology.

First of all, rye leaven was prepared from flour, water and the mother leaven sourdough with Lactobacilli at $1: 1.25: 0.25$ ratio. It was divided into 6 equal pieces, $250 \mathrm{~g}$ each. Six rye leaven samples were prepared with different content of eggshell powder: $1^{\text {st }}$ control, $2^{\text {nd }}$ with $2.5 \mathrm{~g}$ of ESP, for the next, the ESP amount was increased by $2.5 \mathrm{~g}$ respectively till $12.5 \mathrm{~g}$. All leaven samples with different concentration of ESP were mixed and leavened at $32-34{ }^{\circ} \mathrm{C}$ for 12 hours.

Further the bread samples were prepared according to the recipe given in Table 1, which shows ESP content in the sourdough.

Table 1

Recipes of bread samples

\begin{tabular}{lcccccc}
\hline \multirow{2}{*}{ Sample } & \multicolumn{6}{c}{ Ingredients, $\mathbf{g}$} \\
\cline { 2 - 7 } & $\mathbf{C}$ & P2.5 & P5 & P7.5 & P10 & P12.5 \\
\hline Sourdough & 250 & 250 & 250 & 250 & 250 & 250 \\
Eggshell & - & 2.5 & 5.0 & 7.5 & 10 & 12.5 \\
powder & & & & & & \\
Wheat & 510 & 507.5 & 505 & 502.5 & 500 & 497.5 \\
flour 550D & & & & & & \\
Water & 300 & 300 & 300 & 300 & 300 & 300 \\
Sugar & 30 & 30 & 30 & 30 & 30 & 30 \\
Salt & 12 & 12 & 12 & 12 & 12 & 12 \\
Caraway & 10 & 10 & 10 & 10 & 10 & 10 \\
\hline
\end{tabular}

Obtained mass of bread samples was mixed in a mixer "Kitchen Aid" (Germany) for $20 \mathrm{~min}$, the dough was leavened in a thermostat at $32-34{ }^{\circ} \mathrm{C}$ temperature for 120 minutes.

Then the dough was put up in forms, then leavened once more for 30 minutes at $32-34{ }^{\circ} \mathrm{C}$ and baked in an oven "Metos Chef" at $240{ }^{\circ} \mathrm{C}$ for 40 minutes.

Baked goods were stored for $60 \mathrm{~min}$, then placed in plastic bags and stored for 24 hours at room temperature $\left(18-20^{\circ} \mathrm{C}\right)$.

Physical chemical investigation

Loaf volume was measured by rapeseed displacement method, $\mathrm{cm}^{3}$, of the standard ICC 131 . 
Specific volume was calculated as loaf volume to weight ratio, $\mathrm{cm}^{3} \mathrm{~g}^{-1}$, of the standard ICC 131 .

pH was measured by pH-meter ORION 3STAR.

Bread crumb moisture content was determined by drying of a crushed sample at $130 \pm 2{ }^{\circ} \mathrm{C}$ (LST 1492:2013 Bakery goods - Methods for determination of moisture content).

Total titratable acidity expressed as the amount of $\mathrm{NaOH}(\mathrm{mL})$ consumed for the neutralization of free acids per $100 \mathrm{~g}$ of bread sample (LST 1553:1998 Bakery goods and confectionery. Methods for determination of acidity and alkalinity).

The bread porosity index was determined by using the Zuravliov equipment according to the standard LST 1442:1996 Bread, rolls and buns. Determination of porosity.

Sensory evaluation of the breads was carried out using 5 -point scale by a group of 6 assessors. Breads were evaluated for colour, taste, aroma, appearance of crust, texture and overall acceptability, with the score 1-5, where 1 represented extremely disliked and 5 - extremely liked.

Nutrition and energy value calculation method nutritional and energy values were calculated using a specific Excel spreadsheet.

\section{Mathematical statistical analysis of the data}

The wheat bread baking experiments were repeated twice along with the investigation of 6 samples. Mathematical statistical data analysis was performed using SPSS 17.0. P-values less than 0.05 were interpreted as statistically significant.

\section{Results and Discussion}

All six baked bread samples output turned out to be similar and amounted from $88.87 \%$ to $90.89 \%$, the output dependence on the eggshell powder content was not observed. The quality of baked bread depends on the moisture content, volume, crumb grain quality, and the texture of the bread. It was found that upon increasing the eggshell powder the moisture content of the product increased slightly (see Table 2).

Characteristics of bread samples

\begin{tabular}{lccc}
\hline Sample & $\begin{array}{c}\text { Moisture } \\
\text { content, } \\
\%\end{array}$ & $\mathbf{p H}$ & $\begin{array}{c}\text { Total titratable } \\
\text { acidity, } \\
\text { mL 1N NaOH }\end{array}$ \\
\hline C & $39.78 \pm 0.95$ & $4.33 \pm 0.12$ & $4.11 \pm 0.16$ \\
P2.5 & $40.21 \pm 0.75$ & $4.92 \pm 0.09$ & $3.76 \pm 0.14$ \\
P5 & $40.66 \pm 0.68$ & $5.60 \pm 0.10$ & $3.42 \pm 0.10$ \\
P7.5 & $41.56 \pm 0.81$ & $5.87 \pm 0.12$ & $2.75 \pm 0.12$ \\
P10 & $42.28 \pm 0.80$ & $5.95 \pm 0.11$ & $2.40 \pm 0.14$ \\
P12.5 & $42.82 \pm 0.90$ & $5.98 \pm 0.09$ & $2.37 \pm 0.08$ \\
\hline
\end{tabular}

As the difference of the moisture content is low, it can be determined by reduced flour content respectively with the eggshell powder content. Data of other study (Khan et al., 2017) revealed that with the increasing concentration of calcium sources, moisture content of leavened breads and unleavened breads was decreased. The total titratable acidity varied between 2.37 and $4.11 \mathrm{~mL} 1 \mathrm{~N} \mathrm{NaOH}$. There was determined a significant $(\mathrm{p}<0.05)$ increase in the $\mathrm{pH}$ and a decrease in titratable acidity, because the calcium contained in the eggshell neutralizes acids formed in bread during fermentation. Calcium carbonate contained in the eggshell reacts with the acids releasing $\mathrm{CO}_{2}$ gas, which raises the product upon heating, increases the porosity and specific volume of bread (see Table 3).

Table 3

Crumb porosity and specific volume of bread samples

\begin{tabular}{lcc}
\hline Sample & $\begin{array}{c}\text { Crumb porosity, } \\
\mathbf{\%}\end{array}$ & $\begin{array}{c}\text { Specific volume, } \\
\mathbf{c m}^{\mathbf{3}} \mathbf{g}^{\mathbf{1}}\end{array}$ \\
\hline C & $48 \pm 0.49$ & $1.73 \pm 0.11$ \\
P2.5 & $52 \pm 0.40$ & $1.99 \pm 0.06$ \\
P5 & $57 \pm 0.54$ & $2.02 \pm 0.07$ \\
P7.5 & $64 \pm 0.51$ & $2.13 \pm 0.06$ \\
P10 & $68 \pm 0.45$ & $2.21 \pm 0.08$ \\
P12.5 & $67 \pm 0.52$ & $2.16 \pm 0.09$ \\
\hline
\end{tabular}

The quality of the bread crumb can depend on calcium ions which affect the permeability of cell membranes, increase the ability of the yeast fermentation at a concentration from 0.01 to $0.2 \mathrm{~mol}$ (Salinas et al., 2016). Calcium ions also are activators and stabilizers of flour $\alpha$-amylase and amylolytic enzymes, improve the structural and mechanical properties of the bread crumb at the insignificant increase in volume of baked products. However, overdose of this element can inhibit the fermentation process (Young, 1998).

The mean score values of colour, taste, texture and overall acceptability for control and eggshell powder fortified breads are presented in Fig. 1.

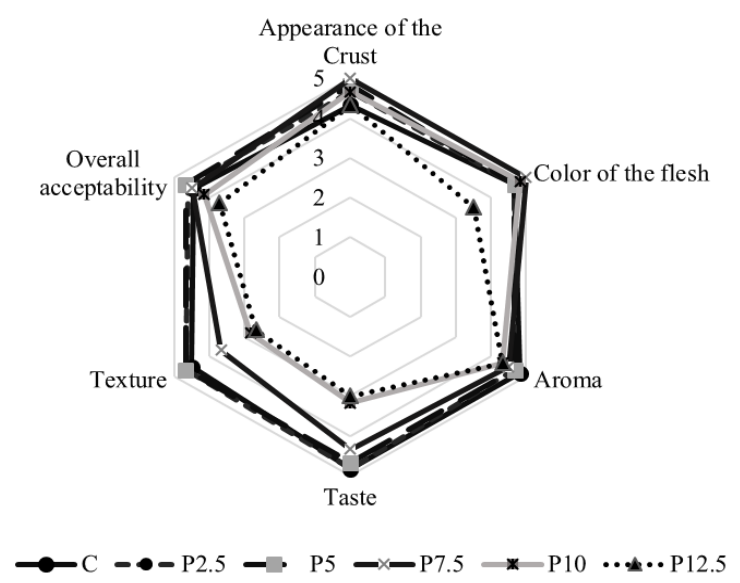

Figure 1. Sensory evaluation of the bread samples C - control, P2.5 - 2.5 g ESP, P5 - 5 g ESP, P7.5 - 7.5 g ESP, P10 - 10 g ESP, P12.5 - 12.5 g ESP

Bread with ESP had a better appearance of the crust colour of the flesh, flavour and overall acceptability compared to control bread, however the taste and flavour remained similar or got worse.

Highest mean appearance of the crust score (5.0) was observed in P7.5 breads. 
Nutrition and energy values of $100 \mathrm{~g}$ bread samples

\begin{tabular}{|c|c|c|c|c|c|c|}
\hline \multirow{2}{*}{ Parametrs } & \multicolumn{6}{|c|}{ Sample } \\
\hline & $\mathrm{C}$ & P2.5 & P5 & P7.5 & P10 & P12.5 \\
\hline Calories, kcal & 222.00 & 221.00 & 220.00 & 220.00 & 219.00 & 218.00 \\
\hline Total fat, g & 1.13 & 1.13 & 1.12 & 1.12 & 1.12 & 1.11 \\
\hline Saturated Fat, g & 0.14 & 0.14 & 0.14 & 0.14 & 0.14 & 0.13 \\
\hline Sodium, mg & 468.78 & 468.77 & 468.76 & 468.74 & 468.73 & 468.72 \\
\hline Total carbohydrates, $\mathrm{g}$ & 47.62 & 47.44 & 47.26 & 47.08 & 46.90 & 46.72 \\
\hline Sugars, $g$ & 3.62 & 3.62 & 3.62 & 3.61 & 3.61 & 3.61 \\
\hline Protein, $\mathrm{g}$ & 6.99 & 6.97 & 6.96 & 6.95 & 6.93 & 6.92 \\
\hline Calcium, mg & 28.77 & 114.01 & 199.25 & 284.49 & 369.74 & 454.98 \\
\hline
\end{tabular}

Table 5

Reference content of nutrients in $100 \mathrm{~g}$ of bread samples, \%

\begin{tabular}{|c|c|c|c|c|c|c|}
\hline \multirow{2}{*}{ Parameters } & \multicolumn{6}{|c|}{ Samples } \\
\hline & Control & P2.5 & P5 & P7.5 & P10 & P12.5 \\
\hline$\overline{\text { Calories }}$ & 11.00 & 11.00 & 11.00 & 11.00 & 11.00 & 11.00 \\
\hline Total fat & 1.60 & 1.60 & 1.60 & 1.60 & 1.60 & 1.60 \\
\hline Saturated fat & 0.70 & 0.70 & 0.70 & 0.70 & 0.70 & 0.70 \\
\hline Sodium & 19.53 & 19.53 & 19.53 & 19.53 & 19.53 & 19.53 \\
\hline Total carbohydrates & 13.60 & 13.60 & 13.50 & 13.50 & 13.40 & 13.30 \\
\hline Sugars & 4.00 & 4.00 & 4.00 & 4.00 & 4.00 & 4.00 \\
\hline Protein & 14.00 & 13.90 & 13.90 & 13.90 & 13.90 & 13.80 \\
\hline Calcium & 3.60 & 14.30 & 24.90 & 35.60 & 46.20 & 56.90 \\
\hline
\end{tabular}

Whereas, ESP at all concentrations decreased the taste score of bread as compared to control (Figure 1). No significant difference in texture of breads was found in control and eggshell powder fortified samples P2.5-P5 but higher ESP content considerably reduced the texture of breads - graininess was perceptible when chewing. Fortification of bread with eggshell powder in various levels significantly $(\mathrm{p}<0.05)$ influenced the overall acceptability. Highest overall acceptability value (4.67) was observed in breads P5 (fortified with $5 \mathrm{~g}$ addition of eggshell powder), which shows the preference of panellist, bread samples P2.5 and P7.5 have also been estimated well.

In order to assess bread nutritional value and calcium content increase, nutritional and energy values were calculated using the recipe and product composition database (see Table 4). Calculation was based on chemical composition of brown eggshells, determined by Dri et al. (2011): protein (6.4\%), lipids $(0.03 \%)$, water $(1.7 \%)$, and amount of calcium $33.13 \pm 0.10 \%$.

As the results showed, the eggshell supplement significantly increased calcium content in all bread samples. Under Regulation (EU) No 1169/2011 of the European Parliament and of the Council of 25 October 2011 on the provision of food information to consumers, adults are recommended to consume $800 \mathrm{mg}$ of calcium per day. Reference calcium content in all bread samples is presented in Table 5.

Calculated reference calcium content in $100 \mathrm{~g}$ significantly increased in all bread samples. If a person consumes $100 \mathrm{~g}$ per day of recommended bread sample
P5, he will receive almost $25 \%$ of the daily recommended amount of calcium.

\section{Conclusions}

Eggshell powder has been perfectly dissolved in rye leaven with lactic acid in 12 hours. Bread with eggshell powder had a better appearance of the crust, colour of the flesh and overall acceptability compared to control bread. The baked products have a texture, crumb structure, taste, and "mouth feel" substantially identical to baked products that do not have added eggshell powder. Bread did not have a "grainy" texture. As calcium was the main concern of the current study, calculated calcium content in $100 \mathrm{~g}$ significantly increased in all bread samples. By best quality indicators was marked bread with $5 \mathrm{~g}$ of eggshell powder.

\section{References}

1. Bradauskienė V., Moščenkova E., Zymonaitė K. (2016) Scientific assumptions on use of eggshell powder as food enrichment with calcium. In: Safe and healthy food challenges and practical experience: proceedings of the conference, p. 11-17.

2. Brun L., Lupo M., Delorenzi D., Di Loreto V., Rigalli A. (2013) Chicken eggshell as suitable calcium source at home. International Journal of Food Sciences and Nutrition, Vol. 64(6), p. 740-743.

3. Daengprok W., Garnjanagoonchorn W., Naivikul O., Pornsinlpatip P., Issigonis K. M. (2003) Chicken Eggshell Matrix Proteins Enhance Calcium Transport in the Human Intestinal Epithelial Cells, Caco-2. Journal of 
Agricultural and Food Chemistry, Vol. 51 (20), p. 60566061.

4. Dri N., Brun L., Di Loreto V., Lupo M., Rigalli A. (2011) Study of the composition of the egg shell. A low cost calcium supplement. Bone, Vol. 49 (6), p. 1381-1388.

5. EP2780114A1 [accessed on 06.02.2016.]. Available at: https://google.com/patents/EP2780114A1?cl=un

6. Food Composition Databases [accessed on 02.03.2016.]. Available at: http://www.smlpc.lt/lt/mityba ir fizinis_aktyvumas/mityba/maisto_produktu_chemines_su deties_duomenu_bankas.html

7. Hirasawa T., Omi N., Ezawa I. (2001) Effect of 1alphahydroxyvitamin D3 and eggshell calcium on bone metabolism in ovariectomized osteoporotic model rats, Journal af Bone and Mineral Metabolism. Vol. 19 (2) p. $84-88$.

8. Juma S., Sohn E., Arjmandi B. H. (1999) Calciumenriched bread supports skeletal growth of young rats. Nutrition Research, Vol. 19(3), p. 389-399.

9. Khan M. R., Wahab S., Qazi I. M., Ayub M., Muhammad A., Uddin Z., Noor M. (2017) Effect of calcium fortification on whole wheat flour based leavened and unleavened breads by utilizing food industrial wastes, Asian Journal of Chemistry, Vol. 29(2), p. $423-430$.

10. LST 1553:1998. Bakery goods and confectionery. Methods for determination of acidity and alkalinity.

11. LST 1442:1996. Bread, rolls and buns. Determination of porosity.

12. LST 1492:2013. Bakery goods - methods for determination of moisture content.

13. Mine Y., Kovacs-Nolan J. (2004) Biologically active hen eggs components in human health and disease. Journal of Poultry Science, Vol. 41, p. 1-29.

14. Neunzehn J., Szuwart T., Wiesmann H. (2015) Eggshells as natural calcium carbonate source in combination with hyaluronan as beneficial additives for bone graft materials, an in vitro study. Head \& Face Medicine, Vol 11, p.1-12.
15. Olgun O., Yildiz A. Ö., Cufadar Y. (2015) The effects of eggshell and oyster shell supplemental as calcium sources on performance, eggshell quality and mineral excretion in laying hens. Indian Journal of Animal Research, Vol 49 (2), p. 205-210.

16. Romanchik-Cerpovicz J. E., McKemie R. J. (2007) Fortification of all-purpose wheat-flour tortillas with calcium lactate, calcium carbonate, or calcium citrate is acceptable. Journal of the American Dietetic Association, Vol. 107(3), p. 506-509.

17. Rovenský J., Stancíková M., Masaryk P., Svík K., Istok R. (2002) Eggshell calcium in the prevention and treatment of osteoporosis. International Journal of Clinical Pharmacology Research, Vol. 23(2-3), p. 83-92.

18. Salinas M. V., Zuleta A., Ronayne P., Puppo M. C. (2016) Wheat bread enriched with organic calcium salts and inulin. A bread quality study. Journal of Food Science and Technology, Vol. 53(1), p. 491-500.

19. Schaafsma I., Pakan G.J.H., Hofstede F.A.J. Muskiet E. Van Der Veer P.J.F., De Vries (2000) Mineral, amino acid, and hormonal composition of chicken eggshell powder and the evaluation of its use in human nutrition. Poultry Science, Vol. 79, p. 1833-1838.

20. Szeleszczuk L., Pisklak D., Kuras M., Wawer I. (2015) In vitro dissolution of calcium carbonate from the chicken eggshell: A study of calcium bioavailability. International Journal of Food Properties, Vol. 18(12), p. 2791-2799.

21. Tamulaitienė M., Alekna V., Aleksandravičiūtė V. (2006) Calcium intake and osteoporosis in older women. Gerontology, Vol. 7(2) p. 88-93.

22. The Agricultural Market Information System, 2016 [accessed on 11.02.2017.]. Available at: https://www.vic.lt/?mid=350\&id=23998

23. Young, L. S. (Ed.). (1998). Technology of Breadmaking. Springer Science \& Business Media.

24. US8221808B2 Calcium fortification of bread dough. [accessed on 04.02.2017.]. Available at: https://www.google.com/patents/US8221808 